\title{
A um passo do anti-pássaro: a poesia de Orides Fontela
}

\author{
One step away from the anti-bird: the poetry of Orides Fontela
}

A un paso del anti-pájaro: la poesía de Orides Fontela

Ivan Francisco Marques*

\section{Resumo}

Orides Fontela, um dos nomes importantes da poesia brasileira na segunda metade do século XX, deixou uma obra composta de poucos títulos, mas sempre admirada pela crítica. Desde a sua estreia no final dos anos 1960, a produção oridiana revela, a par da tendência para a abstração e da busca pela transcendência, uma compreensão aguda da materialidade da existência e dos obstáculos que constituem o mundo real. Este artigo procura ressaltar como aspectos essenciais da poesia de Orides, a presença das marcas do cotidiano, do real e da memória - manifesta, por exemplo, na recorrência do símbolo do sangue -, e também a consciência crítica da autora a respeito do trabalho de criação poética, considerado ao mesmo tempo como racional e sensível. Traços que evidenciam, do ponto de vista da história literária, a sua forte ligação com a tradição brasileira moderna, notadamente com os poetas Carlos Drummond de Andrade e João Cabral de Melo Neto.

Palavras-chave: poesia brasileira moderna, Orides Fontela, metapoesia, memória, poesia e realidade.

\begin{abstract}
Orides Fontela, one of the important names of Brazilian poetry in the second half of the twentieth century, left a work composed of few titles, but always admired by critics. Since its debut in the late 1960s, Oridian production has revealed, alongside the tendency toward abstraction and transcendence, an acute understanding of the materiality of existence and the obstacles that make up the real world. This essay tries to emphasize, as essential aspects of Fontela's poetry, the presence of memory, the quotidian and the real - manifested, for example, in the recurrence of the symbol of blood. This essay also emphasizes the author's critical awareness of poetic creation, considered to be both rational and intuitive, demonstrating, from the point of view of literary history, her strong connection with the modern Brazilian tradition, notably with the poets Carlos Drummond de Andrade and João Cabral de Melo Neto.
\end{abstract}

Keywords: Brazilian modern poetry, Orides Fontela, metalanguage, memory, poetry and reality.

\section{Resumen}

Orides Fontela, uno de los nombres importantes de la poesía brasileña en la segunda mitad del siglo XX, dejó una obra compuesta de pocos títulos, pero siempre admirada por la crítica. Desde su estreno a finales de los años sesenta, la producción oridiana revela, junto a la tendencia hacia la abstracción y la búsqueda de la trascendencia, una comprensión aguda de la materialidad de la existencia y de los obstáculos que constituyen el mundo real. Este ensayo busca enfatizar como aspectos esenciales de la poesía de Orides la presencia de las marcas cotidianas, reales y de la memoria - manifiesta, por ejemplo, en la recurrencia del símbolo de la sangre , y también la conciencia crítica de la autora sobre el trabajo de creación poética, considerado al mismo tiempo como racional y sensible. Rasgos que evidencian, desde el punto de vista de la historia literaria, su fuerte conexión con la tradición brasileña moderna, especialmente con los poetas Carlos Drummond de Andrade y João Cabral de Melo Neto.

Palabras clave: poesía moderna brasileña, Orides Fontela, metalenguaje, memoria, poesía y realidad.

\footnotetext{
* Doutor em literatura brasileira e professor da Universidade de São Paulo (USP), São Paulo, SP, Brasil. (Dorcid.org/0000-0003-3117-9114.E-mail: ivmarques@uol.com.br
} 
A epígrafe de Transposição, livro de estreia de Orides Fontela, publicado em 1969, anuncia a motivação inicial da obra, a busca da transcendência, e também seu limite, ou melhor, sua inevitável ambiguidade:

A um passo de meu próprio espírito

A um passo impossível de Deus.

Atenta ao real: aqui.

Aqui aconteço (Fontela, 2006, p. 8).

Não sendo um fragmento emprestado de outro autor, como em geral ocorre, essa epígrafe tem ainda o poder de sugerir o lugar solitário, fronteiriço e instável, em que se localiza a voz poética. Como observou Augusto Massi, "longe de ser índice de filiação, soa como ponto de partida, compreensão de si, marco zero" (Massi, 1986, p. 61). A singularidade de Orides no meio literário brasileiro, construindo isoladamente a trama de sua "solução pessoal", foi bastante reiterada pela crítica. Com efeito, o que talvez mais impressione o leitor nessas palavras iniciais é a imagem da poeta desbravadora, sentenciosa e até mesmo insolente - cujo espírito "selvagem" se cristaliza na elocução firme e na sonoridade aberta, quase estridente, efeito da repetição da vogal /a/ no interior e, sobretudo, no começo dos quatro versos.

A epígrafe se adequa perfeitamente ao título do livro, sintetizando numa pequena quadra duas acepções da palavra transposição. Ou seja, tanto o sentido da procura, além de um determinado limite, como o da metáfora, "de uma linguagem que vai além de si mesma para dizer o outro, a outra coisa, a semelhança que está além: transposição da experiência para um outro plano" (Arrigucci Jr., 2005, p. 121).

A transposição - se não em ato, completa, ao menos enquanto direção ou ideal, conforme aponta a expressão "a um passo de" - seria, em seus primórdios, a súmula da poética oridiana. Exercício de elevação mística, o trânsito rumo ao conhecimento do ser, na visão da poeta, define a própria arte. Como esta implica, segundo ela, "um impulso essencial para o mais alto", a poesia deveria ser vista como "uma forma seríssima de se aproximar do ser, do real, da divindade" (Fontela, 1997, p. 120). Diferente de outros signos, o símbolo poético reúne os elementos, aproxima-os numa unidade, promove uma espécie de reencontro com a origem. A exemplo de Clarice Lispector, Orides via a literatura como porta para atingir o "real", a essência das coisas. Acreditava que só os artistas poderiam sonhar com esse passo, mesmo sabendo-o impossível.

Depois de marcar profundamente a poética de Transposição, a expressão "a um passo de" retornaria mais uma vez em Alba (1983), terceiro livro da poeta. Numa das epígrafes, reaparecem, bastante modificados, os versos de abertura da coletânea inicial.

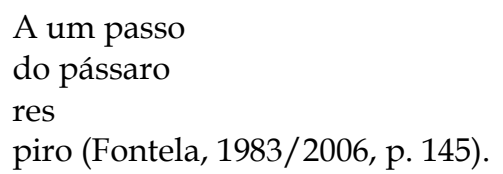

A estrutura é semelhante: quatro versos dispostos em dois pares, o primeiro maior que o segundo. As palavras iniciais são as mesmas ("a um passo"), e o fragmento "res" (coisa, em latim) pode ser visto como eco do substantivo "real", ambos em posições similares, no terceiro verso de cada uma das composições. Mas há também mudanças que servem de amostra das experimentações de linguagem que começam a ocorrer na obra de Orides Fontela. A partir do segundo livro, Helianto (1973), os poemas trazem versos curtos, bruscamente cortados, às vezes formados apenas por uma palavra ou sílaba. A significação do poema passa a depender cada vez mais da maneira como os elementos são arranjados no espaço. Com essa fórmula mais sintética, a epígrafe de Alba, como observou Alcides Villaça (1992, p. 201), promove uma revitalização do sujeito, pois é “imitativa da respiração suspensa ('res / piro'), a sugerir no ritmo a pulsão de um corpo tornado presente... aqui". Letícia Raimundi Ferreira (2002, p. 112) afirma que a condição do poeta é "consumir-se, como coisa do mundo (res, rei) na luz/fogo (pyr, pyrós) de seu sentimento, sucumbir ao peso da realidade existencial, à queda e à divisão inevitáveis, visualmente configuradas na disposição espacial dos versos: res / piro". 
Com efeito, a elevação (transposição) sugerida no primeiro par de versos sofre um forte contraponto no segundo. Depois do som imponente da vogal /a/, quatro vezes repetido, sobrevém, em paralelo com o encurtamento dos versos, o súbito fechamento causado pela vogal tônica /i/ no final da composição. É como se, ao movimento da ascese, sucedesse uma queda repentina, com a entrada em cena - em oposição ao pássaro - de um ser terrestre, corpóreo, escuro, limitado (um "anti-pássaro", conforme denominará mais tarde a poeta?). A epígrafe pesa como uma sentença e parece decretar o fim da ingenuidade que havia no primeiro livro.

Já em Transposição, o passo rumo à transcendência era dado como impossível. Na primeira epígrafe, o movimento seguia duas direções: uma próxima do além ("a um passo de"), a outra estacionada na posição inicial ("aqui"). Alcides Villaça viu nesse advérbio de lugar uma referência ao poema, o locus das palavras onde se dá o "acontecimento" da poesia. Mas também é possível interpretar a expressão "aqui aconteço" como revelação do tempo presente e do espaço terrestre (o mundo) habitado pelo eu lírico.

A poeta parece operar com duas concepções: o real como sinônimo do ser e da divindade, da qual o espírito religioso sonha aproximar-se, e o real no sentido mais corriqueiro do que tem existência verdadeira, de como as coisas realmente são, daquilo de que não se pode fugir. Tendo passado de católica fervorosa a descrente absoluta, Orides gostava de frisar a superação daquela "quase inefável intuição de estar 'a um passo de". A um passo exatamente de quê? Comentário da poeta: "Sei lá, hoje estou a anos-luz" (Fontela, 1991, p. 259).

Desde o início da obra de Orides, por força da ironia, que intercepta o voo lírico, o agigantado descai para os limites do humano e do concreto. É do que trata o poema "Torres", do primeiro livro, espécie de antítese do ideal figurado no título Transposição:

\section{TORRES}

Construir torres abstratas

porém a luta é real. Sobre a luta

nossa visão se constrói. O real

nos doerá para sempre (Fontela, 2006, p. 37).

O poema impressiona pela lucidez do pensamento enunciado de modo preciso e descomplicado. Peça fortemente prosaica, resume-se a uma sentença, desdobrada em quatro versos sem metáforas, de modo lógico e assertivo. A clareza da denotação é uma forma de exprimir a aproximação ao real que, a despeito do título, constitui o foco principal do poema. $\mathrm{O}$ argumento apresentado em "Torres" parece uma resposta à antiga acusação que se move contra o filósofo e o poeta: seu hábito risível de viver nas nuvens ou no mundo da lua, ignorando o que se passa na terra. É também um desabafo contra a "torre de marfim" comumente associada aos poetas herméticos da modernidade, entre os quais se insere a nossa "aristocrata selvagem" (expressão utilizada pelo crítico Nogueira Moutinho).

O poema começa por admitir a verdade geradora do preconceito, isto é, a atitude de "construir torres abstratas". Ato contínuo, a adversativa "porém" introduz um breve arrazoado cuja armação tem um quê de silogismo, a última proposição funcionando como conclusão das duas primeiras (as premissas): se a luta é real, e sobre a luta se constrói "nossa visão", logo, "o real nos doerá para sempre". O enjambement cumpre a função de garantir a coesão do argumento pela leitura continuada dos versos. As reiterações da vibrante /r/, das oclusivas /d/ e /t/ e dos encontros consonantais / tr/, / br/ e /pr/ compõem em cadeia um efeito de travamento. Em "Torres", há total correspondência entre som e sentido, pois o poema fala precisamente de obstáculos, cuja existência as expressões "porém" e "para sempre" tornam ainda mais categórica.

O paradoxo de "construir torres abstratas", sabendo que "a luta é real", poderia ser associado à circunstância contraditória, que Orides sempre lembrava, de escrever poesia enquanto se é obrigado a "viver em prosa" (Marques, 2000). Mas essa seria uma leitura simplória do poema. Não se trata da oposição entre obra e biografia, mas da necessidade, sentida desde os primeiros poemas, de também aprender a poetar em prosa, ou de fazer poesia (abstração) sem esquecer a base concreta (a experiência) em que ela se assenta. O poema se 
chama "Torres", mas o que mostra é, se não a derrocada dessas estruturas elevadas, ao menos sua dependência ou desimportância em face da luta que é real. O lirismo pode parecer abstrato, mas a tarefa de construí-lo (e o verbo exprime com precisão a materialidade de todo o processo) não poderia ter como base o vazio. De acordo com Davi Arrigucci Jr. (2005, p. 119), “Orides não tende a uma abstração lírica para colocar a poesia nas nuvens. Ao contrário, ela puxa para o concreto e a revelação se dá no estar aqui que é problemático, doloroso, sofrido, despojado e neste movimento reside a força moderna da sua poesia".

A poesia pura e a arte abstrata também podem incorporar as feridas do real. É o que afirmam os versos materialistas do poema "Torres", negando o "esquema de distâncias" (expressão utilizada por Orides no poema "Elegia (1)", de Helianto), em favor de uma poética que assume a dimensão menor e mais dramática do lugar ocupado pela autora. No curso do poema "Torres", é fácil notar o adensamento sofrido pela palavra real. Surgindo como adjetivo, ela sofre um processo de substantivação. Se na epígrafe de Transposição a expressão "atenta ao real" provavelmente aludia à essência (divina) do ser, agora "o real" se converte numa espécie de símbolo da existência mundana. Real agora é a luta: base e alimento das abstrações líricas.

Na poesia de Orides Fontela, a par da tendência para o mais alto, existe o senso agudo dos desencontros e obstáculos que constituem o mundo real - um dos traços que a ligam de modo íntimo a Carlos Drummond de Andrade, assumidamente a sua principal influência. A respeito do trajeto de Orides, comentou Davi Arrigucci Jr.:

Orides progrediu muito. Deu um salto extraordinário, superando o verso metrificado do soneto tradicional parnasiano. De repente, ela aprendeu o modernismo como Gullar e outros poetas posteriores. Ela aprendeu por intermédio da leitura dos modernistas. Sua evolução no domínio da linguagem se deve às leituras de nossos poetas (Arrigucci Jr., 2005, p. 121).

"Geneticamente, sou drummondiana", afirmou Orides Fontela (Massi, 1986). Com efeito, Carlos Drummond de Andrade é o poeta mais explicitamente lembrado e celebrado na obra oridiana. Ao todo, são sete homenagens: três poemas curtos, sempre com uma única estrofe, e um composto por quatro partes numeradas. Numa poesia tão contida, chama a atenção esse excesso de citações e paródias, convertendo a gênese ou filiação da autora num dos temas que compõem sua teia de recorrências.

Entre as características da poesia drummondiana, a ironia certamente foi a que mais motivou a forte identificação sentida por Orides. "Gosto do Drummond tiro e queda", dizia a poeta, "aquele dos pequenos poemas que não sobra nada: destrutivos e impressionantes" (Massi, 1986, p. 61). O que mais lhe agradava eram as imagens fortes, definitivas, com as quais o poeta costumava encerrar suas composições. Ao escolher fragmentos de sua obra, Orides dá preferência aos finais de poemas - fechos intrigantes como os de "O sobrevivente", de Alguma poesia, "Edifício Esplendor", de José, e "Morte no avião", de A rosa do povo. Duas vezes ela retoma o verso "uma flor nasceu", acontecimento inesperado que encerra os poemas "Áporo" e "A flor e a náusea". Da longa etapa modernista que se encerra em A rosa do povo - e não, como seria esperado, da fase "filosófica" iniciada com Claro enigma - é que foram extraídos todos os poemas parodiados por Orides. Além dos já mencionados, a lista inclui "Poema de sete faces" e "No meio do caminho", de Alguma poesia, "Soneto da perdida esperança", de Brejo das Almas, e "O boi", de José. Entre as várias faces do poeta, interessoulhe apenas a modernista, o que está de acordo com a busca mais concreta do cotidiano que ocorre nos livros finais Rosácea e Teia, onde se concentram as homenagens.

Em Drummond, Orides escolhe o poeta modernista, cheio de humour, em pleno exercício da dicção coloquial, do verso livre, do poema-piada, de todos os rebaixamentos e provocações empregados com língua solta pelos escritores do modernismo - procedimentos que, embora modificados, perduram em sua produção até a década de 1940. A maior lição recebida foi a poética do vivido: "A poesia é o que é. Se eu não falei de amores nos meus poemas, posso me justificar como Drummond: 'É preciso fazer um poema sobre a Bahia, / mas eu nunca fui lá'. Não amei ninguém. Não escrevo sobre algo sem experiência a respeito, seria uma desonestidade intelectual. Eu falo do que conheço e do que vivi” (Massi, 1989, p. 61). 
No itinerário poético de Orides Fontela, a atenção ao real se intensifica a partir do quarto livro, Rosácea (1986), considerado o fim de uma fase. Embora sua principal característica ainda fosse o lirismo elevado - girando em torno da temática do ser, da poesia, da lucidez -, Rosácea já indica com clareza a disposição de estar mais perto do cotidiano e da memória pessoal, evocada diretamente no poema "Herança" por meio do parco relatório de bens que lhe teriam sido deixados pela família. Essa direção (que se anuncia, como vimos, desde a obra inicial) se tornaria ainda mais clara no último livro, Teia, publicado em 1996. O poema de abertura, em diálogo com João Cabral de Melo Neto, vale por um programa poético:

TEIA

\author{
A teia, não \\ mágica \\ mas arma, armadilha \\ A teia, não \\ morta \\ mas sensitiva, vivente \\ a teia, não \\ arte \\ mas trabalho, tensa \\ a teia, não \\ virgem \\ mas intensamente \\ prenhe: \\ no \\ centro \\ a aranha espera (Fontela, 2006, p. 275).
}

Em várias culturas, a aranha é associada com a criação do cosmo. Orides Fontela a apresenta logo na abertura de Teia como síntese do livro e de sua visão a respeito da criação poética, posta no intervalo entre a inspiração e o trabalho de arte. A imagem da aranha também alude ao problema social que a poeta, àquela altura, vinha desejando incorporar em sua obra, como esclarece em entrevista a Michel Riaudel: "O primeiro poema é de teia de aranha. Um animal bastante proletário, mas para que adotar animais aristocráticos? Eu sou proletária" (Riaudel, 1998, p. 160). Na aranha, o que mais interessa a Orides é sua materialidade, o processo mesmo da tecelagem, numa palavra, sua ligação forte com a ideia de trabalho. Esse o "centro" de onde irradiam os temas e as preocupações do último livro. Trata-se de algo novo e ao mesmo tempo enraizado na obra anterior, como indicam, desde Transposição, os inúmeros poemas sobre telas, tramas, tranças e tecidos. Podemos mesmo eleger a tecelagem - o trabalho - como grande símbolo da poesia de Orides. Nessa teia poética, lentamente constituída ao longo de três décadas, os símbolos se repetem, os fios são continuamente retomados, os versos, sempre refeitos. $\mathrm{O}$ valor individual das composições é suplantado pela força da armação coletiva.

Na construção do poema "Teia", usando um procedimento muito comum na antilírica de João Cabral (e também na prosa "ensaística" de Clarice Lispector), a poeta acumula uma série de tentativas de definição de seu tema. As quatro primeiras estrofes possuem o mesmo sujeito, "a teia", símbolo do trabalho poético. A sintaxe segue também o mesmo padrão, com a presença em cada estrofe de duas predicações: uma negativa, dada por um adjetivo ou substantivo isolado ("mágica", "morta", "arte", "virgem"), e a outra com valor afirmativo, iniciando sempre pelo vocábulo "mas". Nas três primeiras estrofes, cada uma com três versos, essa conjunção é seguida de um par de nomes ("arma, armadilha", "sensitiva, vivente", "trabalho, tensa"), duplicação que amplia esses valores positivos. Na quarta estrofe, ocorre uma variação sintática e rítmica: o número de versos aumenta de três para quatro e, em vez de duas, surge uma única 
qualificação afirmativa ("prenhe"), agigantada pelo advérbio "intensamente". Essa quebra prepara a surpresa da estrofe final, em que ocorre a aparição de um sujeito distinto, embora previsível, "a aranha", e do único verbo de todo o poema, "espera". Embora só apareça no último verso, a aranha é o "centro" do poema. Sua entrada não é repentina, mas engenhosamente anunciada nas estrofes anteriores, seja pela suspensão do paralelismo e do ritmo, seja pela recorrência da sílaba "ar" ("arma", "armadilha", "arte") e de suas variantes "or" e "ir" ("morta", "virgem"), preparando os ouvidos para a chegada da personagem central.

O que espera a aranha? A germinação de um fruto (o poema)? A visita de um leitor? A tensão e a atenção que caracterizam o trabalho poético também serão exigências feitas aos leitores que se deixarem prender pela teia. Calma e paciência - eis as condições necessárias para a boa fruição da poesia. A espera constitui, pois, o princípio básico da poética oridiana. Em seus depoimentos, a autora dizia pertencer à família dos poetas inspirados, limitando-se a anotar os versos que lhe apareciam já prontos. Achava-se incapaz de escrever ao modo racional de João Cabral de Melo Neto. Para ela, poesia não era cosa mentale. De maneira cômica, dizia: "Se eu acreditasse que poesia é trabalho, eu não faria poesia, porque eu não gosto de trabalhar" (Marques, 2000).

No ensaio "Poesia e composição", de 1952, João Cabral considerou predominante na literatura brasileira daquele tempo o conceito de inspiração, isto é, "a atitude do poeta que espera que o poema aconteça, sem jamais forçá-lo a 'desprender-se do limbo'". Segundo ele, para esses poetas a composição seria "o ato de aprisionar a poesia no poema", "o momento inexplicável de um achado", enquanto outros, entre os quais se incluía, preferiam vê-la como atividade intelectual e árdua "procura" (Melo Neto, 1994, p. 723-732). Nos versos de Orides Fontela, porém, a aranha não pratica simplesmente a espera passiva. Da leitura do poema depreende-se toda uma estratégia armada, uma conjugação de esforços a transformar a espera em algo mais agressivo - a espreita, a caça, ou seja, algo menos próximo da inspiração do que de uma "luta corporal" com as palavras. A espera seria um modo de exprimir a "procura da poesia".

A valorização insistente da inspiração poderia ser vista como uma forma irônica encontrada por Orides para explicar o "milagre" de sua poesia ter nascido em meio à indigência material e cultural? Se a vida para ela mostrava-se tão distante da poesia, esta só poderia ter vindo de outro lugar, produzida por algum "fator exterior" - o inconsciente, as musas ou "o que diabo for" (Riaudel, 1998, p. 161). Porém, enquanto isso, nos poemas, afirmava-se a ideia contrária do poeta como fabricante, fazedor, apoiada na reiteração de motivos ligados ao trabalho como a tecelagem, a caça e a agricultura: "Com as mãos nuas / lavrar o campo", afirma Orides, já em seu primeiro livro, no poema "Mãos" (Fontela, 2006, p. 20). Sobretudo, ela gostava de enfatizar seu temperamento antirromântico. Queria recusar a longa tradição sentimental e retórica da poesia em língua portuguesa, nisso seguindo de perto a lição de João Cabral de Melo Neto.

A oposição entre o fortuito e o previsto já havia sido apresentada pelo poeta pernambucano em "Psicologia da composição", de 1947, momento de radicalização de sua poética construtiva. Eis a sexta parte do poema, da qual Orides aproveita não só a sintaxe das predicações negativas (coroadas por um enunciado positivo), mas sobretudo o símbolo da aranha:

Não a forma encontrada

como uma concha, perdida

nos frouxos areais

como cabelos;

não a forma obtida

em lance santo ou raro,

tiro nas lebres de vidro

do invisível;

mas a forma atingida

como a ponta do novelo

que a atenção, lenta, desenrola,

aranha; como o mais extremo 
desse fio frágil, que se rompe

ao peso, sempre, das mãos

enormes (Melo Neto, 1994, p. 95).

“Teia" constitui um tributo à estética cabralina, por meio do qual Orides reafirma - como João Cabral em tantas homenagens a outros artistas - a concepção depuradora e negativa que ela própria possuía da arte poética. Em vez da espera passiva de poema caído do céu, "Teia" propõe, tal como "Psicologia da composição", a armação de uma estratégia baseada em cálculo, método, atenção e paciência. Assim, a teia de Orides pode ser vista como um simulacro da oficina poética cabralina - teia não puramente racional, mas "sensitiva, vivente", símbolo da "vida que se desdobra / em mais vida", ideia recorrente em diversas passagens da obra de João Cabral a partir de $O$ cão sem plumas. Esse parentesco era refutado com veemência pela poeta, mas acabou sendo reconhecido em várias passagens de Teia, sobretudo num dos poemas mais longos da coletânea, "João", no qual aparece a figura do "pássaro-operário", empenhado em cumprir "o duro / impuro / labor: construir-se". Ironicamente, porém, a imagem do humilde joão-de-barro, de modo análogo à da aranha proletária, enfatiza a fragilidade do "construtivismo lírico" de Orides Fontela.

Como escreveu João Cabral, os poetas que valorizam o "trabalho de arte" (não confundir com a "arte" recusada por Orides, que certamente alude a outros significados da palavra, como o dom, a travessura ou a beleza que se pretende perfeita, sendo ainda talvez uma referência ao artesanato rebuscado de poetas como os da geração de 45) acabam por convertê-lo na "origem do próprio poema". A preponderância dada ao "ato de fazer", segundo o autor de O engenheiro, "termina por erigir a elaboração em fim de si mesma" (Melo Neto, 1994, p. 733-735). Nos versos de “Teia”, podemos ver a mesma concepção do trabalho como "fonte da criação". O que a aranha espera não é o acaso, mas o cumprimento de uma intenção fortemente armada. A sedução da presa é o produto de um cálculo, o efeito de uma estratégia, o corolário de um esforço.

Ao longo do poema, como vimos, há um paralelismo rítmico suspenso na passagem da quarta para a última estrofe, na qual surge imperiosa - e não só esperançosa - a figura central do poema. Nas estrofes ímpares, a criação poética é relacionada à razão e ao trabalho, negando-se os excessos apontados como magia e ornamentação. Nas pares, ela surge como criação orgânica, ligada aos motivos da gravidez e da vida, que se opõem às ideias da virgindade e da morte, isto é, o desuso e o esquecimento em geral associados à teia de aranha. $\mathrm{O}$ processo de gestação reaparece em mais dois poemas de Teia. Em "Casulo" se canta a "borboleta futura", "oculto trabalho do sono". Em "Maiêutica" a homenagem a Sócrates também se converte em metalinguagem: "Gerar é escura / lenta / forma in / forme / gerar é / força / silenciosa / firme / / gerar é / trabalho / opaco: // só o nascimento / grita" (Fontela, 2006, p. 280). É fácil notar como o nascimento (o fruto) interessa menos que a gestação lenta e silenciosa. Em “Teia”, de modo semelhante, a expectativa produzida pelo adjetivo "prenhe", seguido dos dois pontos - sequência que encerra a penúltima estrofe, preparando o clímax da composição -, não anuncia o poema enfim nascido ou aprisionado, mas o surgimento triunfal da criatura que pacientemente o espera.

$\mathrm{Na}$ camada sonora, além da mencionada repetição da sílaba "ar", há outras recorrências tramando fios ao longo da composição. Aparecendo quatro vezes, a sílaba "ma" é uma reiteração importante e forma com a primeira um par significativo ("ar-ma"), que prolonga a imagem inicial do poema ("arma, armadilha"). Paralelamente, a repetição da consoante /t/, presente no título e na quase totalidade dos versos, e do fonema nasal /en/ ("sensitiva", "vivente", "tensa", "intensamente", "virgem", "prenhe", "centro"), reforçam as ideias de luta, dificuldade, reiteração do esforço. Ecos, assonâncias e aliterações constroem materialmente a imagem do trabalho contínuo, ininterrupto, incansável. No último verso, desaparecem tanto a consoante /t/ quanto o som nasal /en/, que é substituído pela vogal aberta /é/ - "a aranha espera". Nesse desenlace, dissolve-se a tensão acumulada no poema.

A espera da aranha coincide com a da tecelã Penélope e se espalha por toda a obra de Orides. Além dos que tratam da tecelagem, há um conjunto marcante de poemas que gravita em torno da caça, constituindo todos certa pedagogia da espera, da vigilância, da atenção: "Miro e disparo: / o alvo / o al / o a" ("Alvo"); "Reteso o arco e o / sonho / espero: / / nada 
mais é preciso" ("Odes"); "Astúcia e tempo / (paciência armada)" ("Caça”); "O / leque / fechado: / espera" ("Poemas do leque"); "Momento / pleno: / pássaro vivo / atento a" ("Vigília") etc. (Fontela, 2006). De acordo com Flora Süssekind (2002, p. 334), a caçadora e a tecelã são as duas máscaras usadas pelo eu lírico: "Ora Diana, espécie de sujeito oculto mítico dos poemas de caça, com arcos tesos, mira pronta, capturas. Ora explícita Penélope, tecendo e desfazendo logo depois objetos necessariamente inconclusos, sempre em processo de desmontagem". Como vimos, ambas as personae estão encarnadas no símbolo da aranha.

Outra poética centrada na figura de um animal exemplar pode ser lida em "Coruja". Nesse poema de Rosácea, a criação artística é descrita como atividade a um só tempo racional e sensível - "trabalho opaco", lento e silencioso:

CORUJA

Voo onde ninguém mais - vivo em luz

mínima

Ouço o mínimo arfar - farejo o

sangue

e capturo

a presa

em pleno escuro (Fontela, 2006, p. 203).

Ave noturna, de voo silencioso, a coruja simboliza a reflexão que domina as trevas. A exemplo da aranha, é um bicho sinistro, matreiro, ardiloso. A afinidade com a coruja foi explicada por Orides com um argumento parecido ao da "aranha proletária": "Se eu fosse escolher um pássaro totem, do jeito que eu sou, com óculos e pobre, coruja mesmo" (Marques, 2000). Com efeito, facilmente lhe caberiam as acepções populares do termo "coruja", não apenas o sentido de "mulher feia e de idade avançada", mas também o da pessoa que demonstra admiração por sua cria - narcisismo de que são exemplares a aranha no centro da teia e, sobretudo, a coruja que desfia suas habilidades de caçadora. Para Davi Arrigucci Jr. (2005, p. 115), o poema contém ainda "a agressividade sem peia que também é propriedade dela". Segundo o crítico, a coruja seria uma representação da lucidez destrutiva que era um dos fatores de qualidade da sua lírica, materializando-se no descarnamento das coisas. Acrescentemos que "Coruja" é uma das melhores indicações da "atenção ao real" e do hábito de "farejar sangue", radicalizados pela poeta em sua última fase.

$\mathrm{Na}$ primeira estrofe, quatro orações se sucedem com efeito cumulativo, indicando a aproximação obstinada rumo ao alvo, o cerco realizado em várias frentes. O paralelismo sintático e a pontuação marcada por travessões e enjambements reproduzem o movimento da procura. Como em "Teia", aqui também temos o efeito de uma ação continuada, que obtém o esperado desenlace. A segunda estrofe descreve a captura da presa, enunciada de modo seco numa única oração, dividida em três versos breves, que por sua vez também revelam materialmente - por meio da fragmentação do discurso e da aliteração das consoantes /p/ e /r/ - a surpresa do ataque e o triunfo da caça, a ponto de quase sentirmos a violência da trituração.

Ao contrário da teia silenciosa que se constrói sem nenhum verbo, "Coruja" é um poema cheio de ações, todas comandadas pelo poderoso eu da poeta caçadora. O processo é racionalmente controlado, mas sua vitória depende em última instância da presença forte e conjugada dos sentidos (visão, audição, olfato). A esse respeito, que se recorde o paradoxo observado por Haquira Osakabe: os poemas de Orides são cerebrais, tangenciam a abstração, mas é menos pela razão do que pelos sentidos que eles chegam ao leitor (Osakabe, 2002, p. 104). Em sua procura final pela concretude, a autora passou a ressaltar ainda mais a dimensão corpórea e sensorial do poema. Segundo ela, "Coruja" seria um dos paradigmas dessa proposta: "A ideia está expressa numa coisa mesmo. Aquilo é imagem com bastante concreção. Isso não anda lá muito fácil de conseguir não" (Riaudel, 1998, p. 150).

Entre os poderes da coruja, destaca-se a capacidade de sobreviver na míngua e no escuro ("vivo em luz mínima"), chegando a mover-se em lugares inóspitos, nas moradas obscuras da 
terra. A afirmação inicial, "voo onde ninguém mais", poderia ser vista como uma alusão às alturas frequentadas pela poesia. Porém, as habilidades mais impressionantes são mesmo a atenção do animal e sua resistência em contextos de limitação. A despeito da altivez, "Coruja" evidencia o reconhecimento humilde da contingência.

Ao longo do poema, acumulam-se as restrições - "ninguém mais", "luz mínima", "mínimo arfar", "pleno escuro" -, ecoando mais uma vez a campanha de João Cabral em favor da expressão seca e sintética, reduzida ao "espinhaço", conforme exprime no poema "Graciliano Ramos:", do livro Serial, de 1961: "Falo somente com o que falo: / com as mesmas vinte palavras / girando em redor do sol / que as limpa do que não é faca..." (Melo Neto, 1994, p. 311). Esse manifesto ético e estético, em que se misturam as vozes de Cabral e Graciliano, foi também "imitado" por Orides em Teia.

\section{FALA}

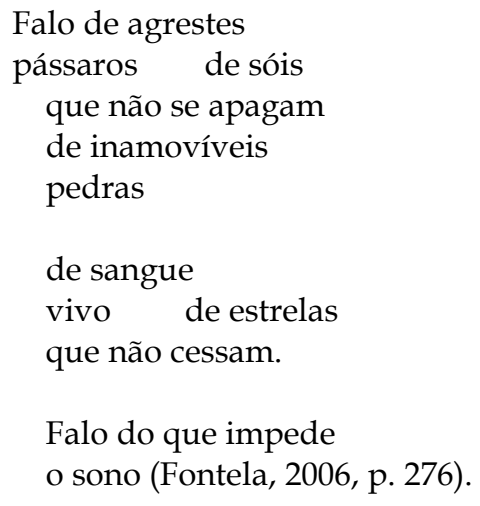

A exemplo dos autores de Vidas secas e Morte e vida severina, Orides Fontela só pretendia cultivar "o que é sinônimo da míngua" (Melo Neto, 1994, p. 312). Embora não tenha nascido na mesma paisagem, seu cotidiano rústico e "selvagem" estava muito próximo da "condição caatinga" revelada pelos dois nordestinos. No trato social, era agreste e agressiva como um Fabiano - alheia como ele às convenções da cidade. Para além da lição sobre o trabalho poético, Orides também extraiu de João Cabral uma orientação útil para o seu projeto de buscar a concreção das imagens. Como o poeta pernambucano, ela se tornou cada vez mais atenta à necessidade de "falar com coisas" (título de um poema do livro Agrestes, publicado nos anos 1980 por João Cabral).

Porém, se atentarmos bem, não é só a voz cabralina que se escuta nos versos de "Fala". O poema em homenagem a Graciliano serviu de base para a composição de Orides - espécie de imitação às avessas, cabralina no tema, mas não na forma e na métrica irregulares -, mas nela se encaixam referências a outros autores: Drummond ("inamovíveis pedras"), Manuel Bandeira ("estrelas que não cessam") e possivelmente Clarice Lispector ("sangue vivo"). Orides Fontela é o "pássaro agreste", procurando, como eles, despertar "sono de morto". Como a deles, a sua palavra também quer ser "sol estridente" - expressão de João Cabral que corresponde à "luz impiedosa" de um famoso poema de Transposição, batizado igualmente de "Fala":

FALA

Tudo será difícil de dizer:

a palavra real nunca é suave.

Tudo será duro:

luz impiedosa

excessiva vivência

consciência demais do ser. 
Tudo será

capaz de ferir. Será

agressivamente real.

Tão real que nos despedaça.

Não há piedade nos signos

e nem no amor: o ser

é excessivamente lúcido

e a palavra é densa e nos fere.

(Toda palavra é crueldade.) (Fontela, 2006, p. 31)

Observem-se as várias espécies de lutas referidas por esses versos: a luta com as palavras, o embate com o real, a violência contra o leitor... Segundo Álvaro Alves de Faria, esse poema apresenta, já no primeiro livro de Orides, "a revelação de toda sua obra poética" (Faria, 2006, p. $\mathrm{xx}$ ). A crueldade - palavra-chave - aparece não só nas duras afirmações do poema, mas também no modo radicalmente assertivo como elas são feitas, com uma artilharia de pronomes indefinidos e totalizadores ("tudo", "toda") e advérbios de intensidade ("tão", "demais", "agressivamente", "excessivamente"), a afastar para longe qualquer possibilidade de alívio ou concessão. Dureza, luminosidade, densidade, agressividade - esses atributos essenciais da "palavra real" de Orides Fontela não fazem lembrar os valores poéticos de João Cabral de Melo Neto? Em outro poema de Transposição, "Núcleo", ela propõe ao modo cabralino uma pedagogia da pedra - "aprender a ser terra / e, mais que terra, pedra" - (Fontela, 2006, p. 23) que pudesse trazer "a palavra definitiva", "áspera e não plástica".

A crueldade contra o leitor consiste em despertá-lo do sono que "oblitera o real", conforme exprime o poema "Acalantos", igualmente do livro de estreia. A atenção ao real e, mais que isso, a importância de ser "agressivamente real", postuladas com firmeza desde Transposição, se radicalizam no último livro. A luz ácida desse instante final levou a poeta a apurar os ouvidos para a escuta dos ruídos do mundo - o "grande rumor" cristalizado na figura do trabalho, onipresente em Teia, conforme já se observou (Cançado, 1996). Atenta ao mundo, a palavra poética de Orides Fontela termina por alinhar-se à melhor tradição realista e crítica de nossa literatura, revelando-se não um acalanto - "a palavra real / nunca é suave" -, mas um acre despertador.

"Eu assassinei a palavra / e tenho as mãos vivas em sangue" - escreveu a autora também em seu livro de estreia, no poema intitulado "Rosa" (Fontela, 2006, p. 33). Assassinar a palavra equivale a contaminá-la com as marcas do real. Esses versos impactantes são uma boa síntese da presença, desde a primeira poesia de Orides Fontela, de um tema insidioso e obsedante: o sangue. No poema "Cisne", de Alba, a poeta escreve: "a palavra fere / o branco / expulsa a presença e - humana - é esplendor memória / e sangue" (Fontela, 2006, p. 153). Na orelha de Trevo, Antonio Candido qualifica como violenta essa criação poética que se dá como rompimento da pureza expressa no branco do papel - "violência que dá nascimento a algo poderoso como a vida, que como ela palpita uma nova presença de sangue" (Candido, 1988). Aparentemente limpa, a lírica de Orides contém nos seus diversos momentos, do primeiro ao último livro, essa corrente subterrânea e escura, a perturbar continuamente a pureza da superfície. Dela é que afloram, inesperadas, as imagens do sangue. Davi Arrigucci Jr. (2005, p. 115) identificou aí a interferência explosiva da "paixão do vivido", brotand o no meio de toda a abstração.

Nas páginas iniciais de A hora da estrela - livro do qual Orides extraiu "Fatos", um dos poemas do livro Teia -, Clarice Lispector promete ao leitor uma narrativa exterior e explícita, de onde "até sangue arfante de tão vivo de vida poderá quem sabe escorrer" (Lispector, 1999, p. 12). A expressão "sangue vivo" aparece mais de uma vez na poesia oridiana. Veículo da vida e das paixões, o sangue corresponde ao calor vital e corporal, em oposição à incorporeidade da luz, que representa o espírito (Chevalier e Gheerbrant, 2008, p. 800). Nas festas profanas de celebração da vida, é indispensável o líquido vermelho: "Para os anjos / a água. Para nós / o vinho encarnado / sempre", dizem os versos de "Bodas de Caná", de Alba. A pureza da água, assim como o branco da aurora, não é capaz 
de exprimir a natureza encarnada do ser - e por essa razão a autora desistirá de simplesmente "dar água", como a moça do poema "Rebeca", de Transposição, para buscar o "sangue do ser" (expressão usada, no mesmo livro, em "Acalantos").

No poema "Alba", da coletânea de mesmo título, assistimos ao dramático encontro entre a "luz" e a "carne" ou, se quisermos, entre o "branco" e o "sangue". O embate arma-se, portanto, desde as primeiras luzes da manhã, isto é, desde o nascimento da vida, em cujo curso as feridas ligadas ao sangue deverão fatalmente irromper. Não nascemos para outra coisa que não a violência do sangue - para "receber o sangue / de todas / as coisas", como repete de modo enfático o poema "Toalha", de Teia. Percorrer a obra de Orides Fontela é perceber, desde o começo, a consciência dessa impossibilidade de "elidir o sangue" (conforme a expressão do citado poema "Rosa"), que se adensará nos livros finais. Em Rosácea, o poema "Anti-gênesis" parece negar drasticamente o que ainda havia, até Alba, de idealização. É o momento em que "a escuríssima / água / bebe / a / luz", criando, em pleno nascedouro da vida, a imagem aterrorizante da "vida finda", da existência escura e impura, da qual se oferece como espelho um lirismo manchado de sangue.

Compreendida como pureza ou abstração, a poesia ficaria muito distante desse ponto vertiginoso em que, alheio à forma instaurada, "custa o sangue a pressentir o horizonte", como se lê em "Aurora (II)", de Transposição. O poeta entregue ao sublime corre o risco de praticar uma indiferença comparável à das "Leis" que "olham do alto", "além do instante e do sangue" (versos de "Marca", também do primeiro livro). A oposição entre alto e baixo é recorrente. No poema "Voo (II)", de Helianto, a par da escalada rumo ao "branco / cume perfeito", também acompanhamos o olhar que se dirige para "a terra muito / abaixo", "muito abaixo o odor / do sangue".

Desprendendo-se cada vez mais das alturas, o sujeito poético buscará com frequência desvelar esse abismo - o sangue - que na poesia de Orides simboliza todo o território do humano: a carne, $\mathrm{o}$ tempo, o real, a memória. Também em Helianto, o poema "Odes" recomenda que se dê ao verbo o seguinte tratamento: "embebê-lo de denso / vinho", transformá-lo em "sonho vivido desde sempre / - real buscado até o sangue". No poema "Prometeu", de Alba, a própria Lei, antes indiferente, "desce e / busca / o Sangue". No mesmo livro, os versos de "Centauros" definem a memória como "rito do / sangue". O deslocamento social está ligado ao reconhecimento de uma "cicatriz" deixada pelas origens - "o sangue / agora / estigma", diz o poema "Memória", de Teia.

Essa poderosa força de gravidade terá o efeito de puxar tudo para seu plano subterrâneo. Pássaros voltarão à terra para descortinar o abismo do sangue - como o pássaro arcaico do poema "Gênesis", de Helianto, ou a mencionada coruja de Rosácea ("farejo o sangue"). Voos serão continuamente interrompidos para que se contemplem os pousos e repousos desses pássaros menos celestes do que agrestes, como se vê no seguinte poema de Teia:

\section{DITADO}

I

Mais vale um

pássaro

na mão pou

sado

que o voo da

ave além

do sangue.

II

Mais vale o

canto

agreste

do que o vívido

silêncio branco

além do humano

sangue. 


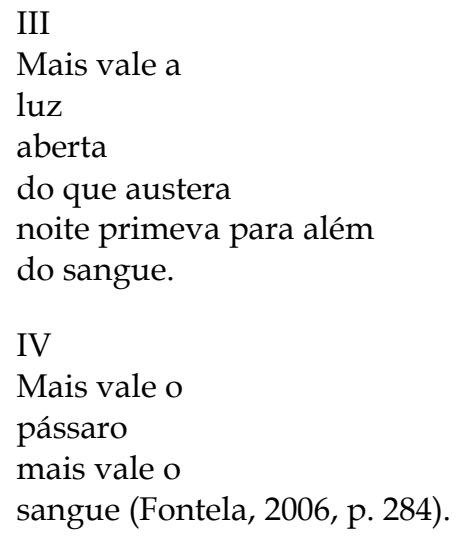

O que se pretende nesses versos não é corrigir a sabedoria popular, na esteira do que fez Chico Buarque na canção "Bom conselho". O objetivo da poeta é reler e refazer a si própria. Como é habitual, "Ditado" remete diretamente a outros poemas de Orides, como "Pouso", de Transposição, "Elegia (I)", de Helianto, e "Pouso (II)", de Alba. Trata-se sempre de uma oposição entre voo e pouso, com nítida valorização do segundo termo. Os itens da primeira série - o pássaro pousado, o canto agreste, a luz aberta - valem mais por sua proximidade em relação à terra e ao sangue (pois a luz, neste caso, está ligada ao calor dos corpos e não à abstração espiritual). Já os elementos da segunda lista - o voo do pássaro, o silêncio branco, a noite primeva - são desqualificados por sua localização em lugares distantes, "para além do sangue".

"Para que serve o pássaro?", perguntava a poeta em "Elegia (I)”, poema incluído em Helianto, mas publicado pela primeira vez em 1965 no jornal O Município, de São João da Boa Vista:

Mas para que serve o pássaro?

Nós o contemplamos inerte.

Nós o tocamos no mágico fulgor das penas.

De que serve o pássaro se

desnaturado o possuímos?

[...] (Fontela, 2006, p. 134)

Agora, em "Ditado", ao afirmar que "mais vale / o pássaro", ela parece desprezar de vez o lirismo alado - o pássaro sem peso decantado pela poesia simbolista -, em favor da poesia pousada na terra. $\mathrm{O}$ "canto agreste", que agora se reverencia, só poderia partir desse pássaro, sequioso de sangue, que em Teia será batizado de "anti-pássaro" (nome de uma das seções mais importantes do livro). Um pássaro meio serpente, colado à terra, circulando, como a poeta, na feiura do lixo urbano. Despojando-se de todo romantismo, Orides Fontela escolherá o abismo em lugar do cume e descerá das alturas para buscar o sangue. Nesse gesto dramático, e não no impulso para a transcendência, talvez tenha se cumprido a sua mais profunda e urgente verdade poética.

\section{Referências}

ARRIGUCCI JR., Davi (2005). Na trama dos fios, tessituras poéticas (depoimento a Cleri Aparecida Biotto Bucioli e Laura Beatriz Fonseca de Almeida). Jandira, Juiz de Fora, n. 2.

BUCIOLI, Cleri Aparecida Biotto (2003). Entretecer e tramar uma teia poética: a poesia de Orides Fontela. São Paulo: Anablume; Fapesp.

CANÇADO, José Maria (1996). A eutanásia da biografia. Folha de S. Paulo, São Paulo, Caderno Mais, p. 12, 12 maio.

CANDIDO, Antonio (1983). Prefácio. In: FONTELA, Orides. Alba. São Paulo: Roswitha Kempf, p. 3-7.

CANDIDO, Antonio (1988). Orelha. In: FONTELA, Orides. Trevo. São Paulo: Duas Cidades. 
CASTELLO, José (1996). Orides Fontela resiste à sofisticação da poesia. O Estado de S. Paulo, São Paulo, Caderno 2, p. 115, $1^{\circ}$ jun.

CHAUÍ, Marilena (1996). Prefácio. In: FONTELA, Orides. Teia. São Paulo: Geração, p. 9.

CHEVALIER, Jean; GHEERBRANT, Alain (2008). Dicionário de símbolos. Tradução de Vera da Costa e Silva (et al.). Rio de Janeiro: José Olympio.

DANTAS, Vinicius (1986). A nova poesia brasileira e a poesia. Novos Estudos CEBRAP, São Paulo, v. 3, n. 16, p. 40-53, dez.

FARIA, Álvaro Alves de (2006). Tristeza difícil de apagar. Rascunho, Curitiba, n. 77, set.

FERREIRA, Letícia Raimundi (2002). A lírica dos símbolos em Orides Fontela. Santa Maria: Associação SantaMariense de Letras.

FONTELA, Orides (2006). Poesia reunida (1969-1996). São Paulo: Cosac Naify; Rio de Janeiro: 7 Letras.

FONTELA, Orides (1991). Nas trilhas do trevo. In: MASSI, Augusto (Org.). Artes e ofícios da poesia. Porto Alegre: Artes e Ofícios, p. 255-261.

FONTELA, Orides (1997). Uma - despretensiosa - minipoética. Cultura Vozes, ano 91, n. 1, p. 118-125, jan./fev.

FONTELA, Orides (1998). Sobre poesia e filosofia - um depoimento. In: PUCHEU, Alberto (Org.). Poesia (e) filosofia. Rio de Janeiro: 7 Letras, p. 13-16.

LISPECTOR, Clarice (1999). A hora da estrela. Rio de Janeiro: Rocco.

MARQUES, Ivan (2000). Orides: a um passo do pássaro (documentário). São Paulo: TV Cultura, 26 maio 2000.

MASSI, Augusto (1986). Uma obra feita em espiral. Folha de S. Paulo, São Paulo, Caderno Ilustrada, p. 61, 9 ago.

MELO NETO, João Cabral de (1994). Poesia e composição. In: MELO NETO, João Cabral de. Obra completa. Rio de Janeiro: Nova Aguilar.

OSAKABE, Haquira (2002). O corpo da poesia. Notas para uma fenomenologia da poesia, segundo Orides Fontela. Remate de males, Campinas, n. 22, n. 2, p. 97-109.

RIAUDEL, Michel (1998). Entretien avec Orides Fontela. In: QUINT, Anne-Marie (Ed.). Le conte et la ville: études de littérature portugaise et brésilienne. Paris: Presses de La Sorbonne Nouvelle.

SÜSSEKIND, Flora (2002). Seis poetas e alguns comentários. In: SÜSSEKIND, Flora. Papéis colados. Rio de Janeiro: Editora da UFRJ.

VILLAÇA, Alcides (1992). Símbolo e acontecimento na poesia de Orides. Novos Estudos CEBRAP, São Paulo, v. 3, n. 34, p. 198-2014, nov.

VILLAÇA, Alcides (1996). O silêncio de Orides. Folha de S. Paulo, São Paulo, Jornal de Resenhas, p. 7, 12 jul. 